\title{
Importance and Reality of TDM for Antibiotics Not Covered by Insurance in Japan
}

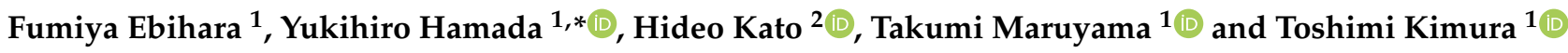 \\ 1 Department of Pharmacy, Tokyo Women's Medical University Hospital, Tokyo 162-8666, Japan; \\ ebihara.fumiya@twmu.ac.jp (F.E.); maruyama.takumi@twmu.ac.jp (T.M.); kimura.toshimi@twmu.ac.jp (T.K.) \\ 2 Department of Pharmacy, Mie University Hospital, Mie 514-8507, Japan; \\ katou.hideo.233@mail.aichi-med-u.ac.jp \\ * Correspondence: hamada.yukihiro@twmu.ac.jp
}

check for

updates

Citation: Ebihara, F.; Hamada, Y.; Kato, H.; Maruyama, T.; Kimura, T. Importance and Reality of TDM for Antibiotics Not Covered by Insurance in Japan. Int. J. Environ. Res. Public Health 2022, 19, 2516. https://doi.org/10.3390/ ijerph19052516

Academic Editor: Paul B.

Tchounwou

Received: 9 February 2022

Accepted: 19 February 2022

Published: 22 February 2022

Publisher's Note: MDPI stays neutral with regard to jurisdictional claims in published maps and institutional affiliations.

Copyright: (c) 2022 by the authors. Licensee MDPI, Basel, Switzerland. This article is an open access article distributed under the terms and conditions of the Creative Commons Attribution (CC BY) license (https:/ / creativecommons.org/licenses/by/ $4.0 /)$.

\begin{abstract}
Under the Japanese health insurance system, medicines undergoing therapeutic drug monitoring (TDM) can be billed for medical fees if they meet the specified requirements. In Japan, TDM of vancomycin, teicoplanin, aminoglycosides, and voriconazole, which are used for the treatment of infectious diseases, is common practice. This means the levels of antibiotics are measured in-house using chromatography or other methods. In some facilities, the blood and/or tissue concentrations of other non-TDM drugs are measured by HPLC and are applied to treatment, which is necessary for personalized medicine. This review describes personalized medicine based on the use of chromatography as a result of the current situation in Japan.
\end{abstract}

Keywords: HPLC; TDM; ceftriaxone; daptomycin; linezolid

\section{Introduction}

In Japan, insurance claims based on therapeutic drug monitoring (TDM) became possible for lithium carbonate in the treatment of manic depression in 1980, followed by antiepileptic drugs and digitalis the following year. Since then, the therapeutic benefits of TDM have been confirmed, the number of drugs covered has gradually expanded, and insurance billing rates have increased. When the blood concentration of the administered drug is measured and the dosage is precisely controlled based on the results, the associated costs can be calculated and billed only once in a calendar month.

The insurance billing fee includes the costs for measuring the blood drug concentration, drawing blood for this measurement, and administering of the dosage based on the results, and the cost of measuring the blood concentration more than once in a single month cannot be calculated separately. In addition, the blood concentration of the drug and the main points of the treatment plan should be detailed in the medical record.

In the 1980s and 1990s, high-performance liquid chromatography (HPLC) played a significant role in the analysis of drug concentrations in blood. However, with the spread of simple automated analyzers based on ligand-binding assays and the promotion of outsourcing to clinical laboratories, the number of medical institutions with HPLC capability has decreased [1]. In the area of clinical toxicology, precision analytical equipment was installed in emergency departments in 1998 with support from the Ministry of Health, Labor, and Welfare, but most of the equipment are systems for high-performance liquid or gas chromatography coupled with mass spectrometer detectors; not many facilities use HPLC with UV-visible detectors as their main equipment [2,3].

Focusing on drugs for infectious diseases, the only drugs that can be billed to insurance in Japan are vancomycin, teicoplanin, aminoglycoside antibiotics, and voriconazole. In some facilities, the blood and tissue concentrations of other drugs are measured by HPLC and are applied to treatment, which is necessary for personalized medicine. In this paper, we focus on antibiotics that are not covered by insurance and introduce the clinical 
significance of TDM and methods for measuring blood concentrations with examples from our own experience. In this review, we discussed ceftriaxone (CTRX), whose blood and tissue concentrations were actually measured at our hospital, and daptomycin (DAP), linezolid (LZD), and tedizolid (TZD), which are listed in the Japanese Antimicrobial Agents TDM Guidelines 2022 [4].

\section{TDM of Ceftriaxone}

\subsection{Characteristics of Ceftriaxone and Significance of TDM}

CTRX is a third-generation cephalosporin that has a broad antibacterial spectrum, good tissue migration, and a longer half-life than other cephalosporins, allowing for oncedaily administration. CTRX has been used for a variety of indications and has many opportunities for use [5]. In addition, dose adjustment is not necessary for patients with impaired renal function [6]. Patel et al. reported that adjusting the dosage regimen of ceftriaxone for patients with impaired renal function should not be necessary when the daily dosage is $2 \mathrm{~g}$ or lower [7]. Antibiotic-associated encephalopathy (AAE) is a known side effect of cephalosporins. AAE is classified into three major categories: type I for cephalosporins and penicillins, type II for quinolones and macrolides, and type III for metronidazole; type I is said to be free of epileptic waves [8]. In particular, there have been many reports on AAE with cefepime (CFPM), a fourth-generation cephalosporin drug, including reports on the intoxication zone of blood levels responsible for AAE [9-11]. There are also scattered reports of AAE caused by CTRX, and according to an adverse drug reaction database study in France, the serious CNS adverse effects caused by CTRX and CFPM were reported to be similar [12]. AAE with CTRX has been reported more frequently in the elderly and patients with chronic kidney disease and is more likely to occur when high doses are given and blood and cerebrospinal fluid (CSF) concentrations are high [13-15].

In a recent report, Lacroix et al. [16] used the French pharmacovigilance database to analyze records of CNS adverse events due to CTRX that were recorded as occurring in 1995-2017. A total of 152 serious adverse drug reactions (ADRs) were analyzed: 112 resulted in hospitalization or prolonged hospitalization $(73.7 \%), 12$ resulted in death $(7.9 \%)$, and 16 were life-threatening. The median age was 74.5 years, and the median rate of creatinine clearance (CLcr) was $35 \mathrm{~mL} / \mathrm{min}$. The median time of onset was 4 days; the mean daily dose was $1.7 \mathrm{~g}$, with three patients receiving doses exceeding the maximum recommended dose; and plasma ceftriaxone levels were recorded in 19 patients $(12.5 \%)$, with eight patients exceeding the threshold for toxicity $(>100 \mu \mathrm{g} / \mathrm{mL})$. In addition, electroencephalography performed on 50 patients $(32.9 \%)$ showed abnormalities in $37(74 \%)$.

Although the frequency of CTRX-related encephalopathy in Japan is not clear, it has been reported that the sales volume of third-generation cephalosporins is about six times higher than that of fourth-generation cephalosporins [17], and caution is required.

\subsection{Report on the Measurement of Blood Levels and CSF of CTRX in Japan}

In Japan, we searched for clinically applied studies on CTRX that are not generally clinically measured. As a result, we present reports on the measurement of CTRX concentrations in cerebrospinal fluid by HPLC-UV in Japan.

Kotani et al. [18] measured CTRX concentrations in CSF samples collected from peritoneal dialysis patients diagnosed with CTRX-induced encephalopathy (CIE) using an HPLC-UV system to investigate whether high CTRX concentrations in CSF are associated with CIE. Their study used an octadecyl silica (ODS) column, methanol, and a mobile phase of mixed solution $(25: 75, v / v)$ in $10 \mathrm{mM}$ phosphate to accurately analyze the CSF samples from CIE patients; the detection wavelength was $280 \mathrm{~nm}$. Based on the current HPLC-UV capability, a linear range of $0.1-100 \mu \mathrm{g} / \mathrm{mL}(\mathrm{r}=0.999)$ was obtained. In a recovery study using a blank sample of human CSF and a control serum supplemented with CTRX, the recovery of CTRX was $\geq 95.3 \%$, and the RSD was $<5.8 \%(n=3)$. CTRX in CSF and serum obtained from a patient diagnosed with CIE was measured using the 
developed HPLC-UV system. The concentration of CTRX in CSF and serum was 2.61 and $37.35 \mu \mathrm{g} / \mathrm{mL}$, respectively. We simulated the serum and CSF concentrations of CTRX using simulation software developed by Oda (Figure 1) [19].

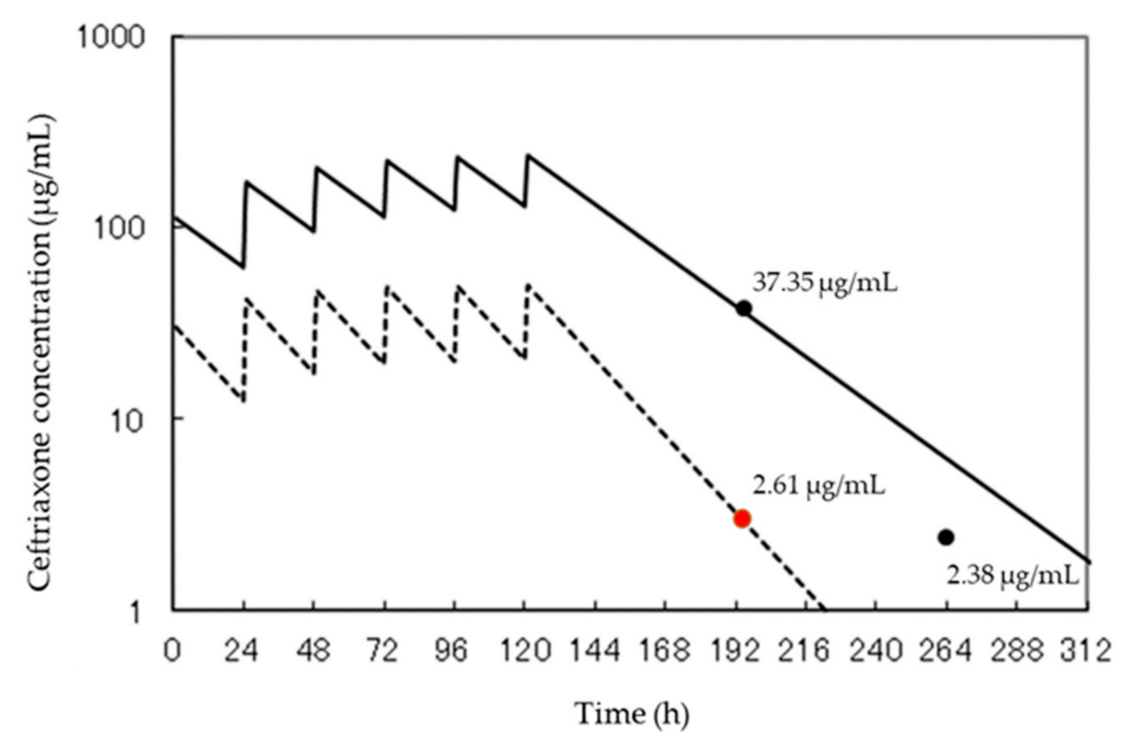

Figure 1. Simulation of blood concentration and human cerebrospinal fluid after ceftriaxone administration [18]. We completed the simulation ourselves using our results. The solid line shows changes in blood concentration after ceftriaxone administration, and the dotted line shows changes in cerebrospinal fluid.

Suzuki et al. [20] reported the case of a patient with renal failure who experienced encephalopathy induced by CTRX. An 86-year-old woman undergoing maintenance hemodialysis was treated with CTRX for Helicobacter cinaedi bacteremia, and her mental status worsened during antibiotic administration. During the period when CTRX was administered at $2 \mathrm{~g} /$ day, the measured plasma and CSF CTRX concentrations were high (>100 and $10.2 \mu \mathrm{g} / \mathrm{mL}$, respectively). The patient reported that her mental status improved after the antibiotic treatment was stopped. Table 1 shows the PubMed search results for reports that measured blood and CSF concentrations of CTRX, DAP, LZD, and TZD in Japan.

In Japan, the measurement of the CTRX blood concentration is not covered by insurance and is limited to facilities with appropriate laboratory equipment. In practice, there is a time lag between collecting samples and obtaining blood concentration results, making it difficult to use them for differential diagnosis in real time. LC-MS systems can measure blood levels more accurately than HPLC systems, but are expensive and therefore impractical. In the future, it would be desirable to have a test system that can be used in general practice so that the CTRX blood concentration can be measured when AAE is suspected. These reports suggest that TDM of CTRX may be able to prevent the occurrence of AAE. 
Table 1. Summary of Japanese reports on serum and CSF concentrations of CTRX, DAP, LZD, and TZD [18,20-33].

\begin{tabular}{|c|c|c|c|c|c|c|c|c|c|}
\hline Drug & Characteristics & Objective & Renal Function & Dose & $\begin{array}{l}\text { Measurement } \\
\text { System }\end{array}$ & Measurement Accuracy & $\begin{array}{c}\text { Blood } \\
\text { Concentration }\end{array}$ & $\begin{array}{c}\text { CSF } \\
\text { Concentration }\end{array}$ & Ref. \\
\hline \multirow{3}{*}{ CTRX } & $\begin{array}{l}\text { Age: } 75 \text { Sex: } \\
\text { female }\end{array}$ & $\begin{array}{l}\text { Development of HPLC } \\
\text { method for accurate, } \\
\text { precise, and selective } \\
\text { determination of } \\
\text { CTRX and its } \\
\text { clinical application }\end{array}$ & $\begin{array}{l}\text { peritoneal } \\
\text { dialysis }\end{array}$ & $2 \mathrm{~g} /$ day & HPLC-UV & $\begin{array}{c}\text {-Chromatographic peak heights of } \\
\text { CTRX: 0.1-100 } \mu \mathrm{g} / \mathrm{mL}(\mathrm{r}=0.999) \\
\text {-Detection limit of CTRX: } \\
35 \mathrm{ng} / \mathrm{mL} \\
\text {-Repeatability }(n=6) \text { of the } \\
\text { chromatographic peak height for } \\
4.0 \mu \mathrm{g} / \mathrm{mL} \text { CTRX: } 0.38 \% \\
\text { RSD.-Recovery rates of CTRX: } \\
>95.3 \% \text {, and these RSDs } \\
\text { were }<5.8 \%\end{array}$ & $37.35 \mu \mathrm{g} / \mathrm{mL}$ & $2.61 \mu \mathrm{g} / \mathrm{mL}$ & [18] \\
\hline & $\begin{array}{l}\text { Age: } 86 \text { Sex: } \\
\text { female }\end{array}$ & $\begin{array}{c}\text { Report of } \\
\text { encephalopathy } \\
\text { associated with high } \\
\text { levels of ceftriaxone in } \\
\text { plasma and } \\
\text { cerebrospinal fluid, } \\
\text { investigation of the } \\
\text { causal relationship } \\
\text { between ceftriaxone } \\
\text { administration and the } \\
\text { development of } \\
\text { encephalopathy }\end{array}$ & hemodialysis & $2 \mathrm{~g} /$ day & HPLC & nd & $>100 \mu \mathrm{g} / \mathrm{mL}$ & $10.2 \mu \mathrm{g} / \mathrm{mL}$ & {$[20]$} \\
\hline & $\begin{array}{c}\text { Population: } \\
n=43 \text { patients } \\
\text { Sex: male } \\
\text { median age: } \\
51.7 \text { years (IQR } \\
33.3-67.1) \\
\text { median BMI: } \\
24.7 \mathrm{~kg} / \mathrm{m}^{2}(\mathrm{IQR} \\
\left.22.4-27.7 \mathrm{~kg} / \mathrm{m}^{2}\right)\end{array}$ & $\begin{array}{l}\text { Determining the role of } \\
\text { transporter genetic } \\
\text { variation and } \\
\text { blood-brain barrier } \\
\text { permeability in } \\
\text { predicting ceftriaxone } \\
\text { exposure in the central } \\
\text { nervous system }\end{array}$ & $\begin{array}{l}\text { estimated } \\
\text { creatinine } \\
\text { clearance } \\
<30 \mathrm{~mL} / \mathrm{min}\end{array}$ & $2 \mathrm{~g}$ twice a day & HPLC & $\begin{array}{c}\text {-Detection limits: } 0.24 \mathrm{mg} / \mathrm{L} \text { in } \\
\text { plasma and } 0.5 \mathrm{mg} / \mathrm{L} \text { in CSF } \\
\text {-Accuracy: } 5.2 \% \text { for plasma, } 7.2 \% \\
\text { for CSF } \\
\text {-Intra- and inter-day coefficients of } \\
\text { variation }(\mathrm{CV} \%): 3.6 \% \text { and } 4.5 \% \text { for } \\
\text { plasma samples, and } 7.2 \%, 7.8 \% \text {, } \\
\text { and } 10.3 \% \text { for CSF samples } \\
\text {-Recovery rate: } 86 \%(C V \%=3) \text { for } \\
\text { CSF samples and } 82 \%(C V \%=8) \\
\text { for plasma samples. }\end{array}$ & $\begin{array}{l}\text { Median Cmax: } \\
\text { 157,193.00 ng/mL } \\
\text { (IQR 105,164.0- } \\
184,852.0 \mathrm{ng} / \mathrm{mL} \text { ) }\end{array}$ & $\begin{array}{l}\text { Median Cmax: } \\
3512.0 \mathrm{ng} / \mathrm{mL} \\
(\mathrm{IQR} 2134.0- \\
6193.0 \mathrm{ng} / \mathrm{mL} \text { ) }\end{array}$ & [21] \\
\hline
\end{tabular}


Table 1. Cont.

\begin{tabular}{|c|c|c|c|c|c|c|c|c|c|}
\hline Drug & Characteristics & Objective & Renal Function & Dose & $\begin{array}{l}\text { Measurement } \\
\text { System }\end{array}$ & Measurement Accuracy & $\begin{array}{c}\text { Blood } \\
\text { Concentration }\end{array}$ & $\begin{array}{c}\text { CSF } \\
\text { Concentration }\end{array}$ & Ref. \\
\hline & $\begin{array}{l}\text { Population: } \\
n=16 \text { patients }\end{array}$ & $\begin{array}{c}\text { Evaluation of } \\
\text { tolerability and } \\
\text { pharmacokinetic } \\
\text { parameters of } \\
\text { high-dose ceftriaxone in } \\
\text { adult patients treated } \\
\text { for central nervous } \\
\text { system infections: } \\
\text { pharmacological data } \\
\text { from two French } \\
\text { cohorts }\end{array}$ & nd & $\begin{array}{c}6.5 \mathrm{~g} / \text { day } \\
\text { (range 4-9 g) } \\
97.5 \mathrm{mg} / \mathrm{kg} \\
(\text { range } 77- \\
131 \mathrm{mg} / \mathrm{kg} \text { ) }\end{array}$ & HPLC & nd & $\begin{array}{c}\text { Median total } \\
\text { plasma: } \\
69.3 \mathrm{mg} / \mathrm{L} \\
\text { (range } 21.6- \\
201.3 \mathrm{mg} / \mathrm{L} ; \\
n=14 \text { ) Median } \\
\text { unbound } \\
\text { plasma: } \\
7.95 \mathrm{mg} / \mathrm{L} \text { (range } \\
0.8-43.7 \mathrm{mg} / \mathrm{L} ; \\
n=8 \text { ) }\end{array}$ & $\begin{array}{c} \\
\text { Median: } \\
13.3 \mathrm{mg} / \mathrm{L} \\
\text { (range } \\
0.9-91.2 \mathrm{mg} / \mathrm{L})\end{array}$ & {$[22]$} \\
\hline & $\begin{array}{l}\text { Population: } \\
n=7 \text { patients }\end{array}$ & $\begin{array}{l}\text { Investigation of the } \\
\text { pharmacokinetics } \\
\text { ofboth antibiotics in } \\
\text { patients with non- } \\
\text { inflammatory } \\
\text { obstructive } \\
\text { hydrocephalus } \\
\text { undergoing external } \\
\text { ventricular surgery } \\
\text { treated with cefotaxime } \\
\text { or ceftriaxone for } \\
\text { extracerebral infections }\end{array}$ & $\mathrm{Scr}<1.5 \mathrm{mg} / \mathrm{dL}$ & $\begin{array}{l}2 \mathrm{~g} \text { single dose } \\
30 \mathrm{~min}\end{array}$ & HPLC-UV & $\begin{array}{c}\text {-Quantification limits of } \\
\text { ceftriaxone; } 0.8 \mathrm{mg} / \mathrm{L} \text { in serum } \\
\text { and } 0.08 \mathrm{mg} / \mathrm{L} \text { in CSF. } \\
\text {-Interday coefficients of variation; } \\
2.0 \% 249.6 ; n=6) \text { at } 99.7 \text { and } 6.8 \% \\
\text { at } 1.55 \mathrm{mg} / \mathrm{L} \text { inserum and } 3.3 \% \text { at } \\
16.2 \text { and } 6.4 \% \text { at } 0.16 \mathrm{mg} / \mathrm{L} \text { in CSF } \\
(n=6) .\end{array}$ & $\begin{array}{c}\text { Cmax: } 172.2- \\
271.7 \mathrm{mg} / \mathrm{L} \\
\text { (median = 249.6; } \\
n=6 \text { ) }\end{array}$ & $\begin{array}{c}\text { Cmax: } \\
0.18-1.04 \mathrm{mg} / \mathrm{L} \\
\text { (median = 0.43; } \\
n=5 \text { ), } \\
\text { confirmed } \\
1-16 \mathrm{~h} \text { after } \\
\text { injection } \\
\text { (median = } 12 \mathrm{~h} ; \\
n=5 \text { ). }\end{array}$ & [23] \\
\hline DAP & $\begin{array}{c}\text { Population: } 16 \text { pa- } \\
\text { tients ( } 8 \text { males } \\
\text { and } 8 \text { females) } \\
\text { Age: } \\
70.0 \pm 3.4 \text { years } \\
\text { weight: } \\
47.6 \pm 5.0 \mathrm{~kg}\end{array}$ & $\begin{array}{l}\text { Investigate the optimal } \\
\text { dosing regimen for } \\
\text { daptomycin and } \\
\text { determine the need and } \\
\text { appropriateness of a } \\
\text { high-dose regimen in } \\
\text { terms of PK / PD } \\
\text { parameters using } \\
\text { Monte Carlo Simulation } \\
\text { and TDM in a Japanese } \\
\text { clinical setting }\end{array}$ & $\begin{array}{l}\text { CLcr 16.2- } \\
\text { 173.4 mL/min } \\
(n=11) \\
\text { hemodialysis } \\
(n=5)\end{array}$ & $\begin{array}{l}\text { single doses } \\
(6 \mathrm{mg} / \mathrm{kg}, \\
8 \mathrm{mg} / \mathrm{kg} \text {, } \\
10 \mathrm{mg} / \mathrm{kg} \text {, and } \\
12 \mathrm{mg} / \mathrm{kg}) \\
\text { and dosing } \\
\text { intervals }(24 \mathrm{~h} \\
\text { and } 48 \mathrm{~h})\end{array}$ & HPLC-UV & $\begin{array}{l}\text {-Lowest limit of quantification: } \\
\qquad 0.78 \mu \mathrm{g} / \mathrm{mL}\end{array}$ & $\begin{array}{l}\text { Cmin: } 0.13- \\
49.4 \mu \mathrm{g} / \mathrm{mL} \\
\text { Cpeak: } 34.2- \\
130.0 \mu \mathrm{g} / \mathrm{mL}\end{array}$ & nd & [24] \\
\hline
\end{tabular}


Table 1. Cont.

\begin{tabular}{|c|c|c|c|c|c|c|c|c|c|}
\hline Drug & Characteristics & Objective & Renal Function & Dose & $\begin{array}{l}\text { Measurement } \\
\text { System }\end{array}$ & Measurement Accuracy & $\begin{array}{c}\text { Blood } \\
\text { Concentration }\end{array}$ & $\begin{array}{c}\text { CSF } \\
\text { Concentration }\end{array}$ & Ref. \\
\hline & $\begin{array}{c}\text { Population: } \\
n=20 \text { patients }\end{array}$ & $\begin{array}{l}\text { Investigate associations } \\
\text { between DAP Cmin } \\
\text { and creatine } \\
\text { phosphokinase } \\
\text { elevation via logistic } \\
\text { regression analysis } \\
\text { (E/R analysis), and to } \\
\text { analyze DAP PPK via } \\
\text { adaptation of a } \\
\text { one-compartment } \\
\text { model in Japanese } \\
\text { patients to determine } \\
\text { optimal DAP doses for } \\
\text { minimizing adverse } \\
\text { effects and maximizing } \\
\text { treatment success by } \\
\text { E/R analysis. }\end{array}$ & $\begin{array}{c}\text { CLcr 22.4- } \\
213.8 \mathrm{~mL} / \mathrm{min}\end{array}$ & $2.8-8.6 \mathrm{mg} / \mathrm{kg}$ & HPLC-UV & $\begin{array}{l}\text {-Lowest limit of quantitation: } \\
\qquad 1.0 \mu \mathrm{g} / \mathrm{mL} \\
\text {-within-day and between-day } \\
\text { coefficients of variation of }<5.0 \% \text {. }\end{array}$ & $\begin{array}{l}\text { Cmin: } \\
\text { 2.8-92.4 } \mu \mathrm{g} / \mathrm{mL} \\
\text { Cpeak: } 30.4- \\
76.7 \mu \mathrm{g} / \mathrm{mL}\end{array}$ & nd & [25] \\
\hline
\end{tabular}


Table 1. Cont.

\begin{tabular}{|c|c|c|c|c|c|c|c|c|c|}
\hline Drug & Characteristics & Objective & Renal Function & Dose & $\begin{array}{l}\text { Measurement } \\
\text { System }\end{array}$ & Measurement Accuracy & $\begin{array}{c}\text { Blood } \\
\text { Concentration }\end{array}$ & $\begin{array}{c}\text { CSF } \\
\text { Concentration }\end{array}$ & Ref. \\
\hline & $\begin{array}{c}\text { Population: two } \\
\text { patients } \\
\text { admitted to } \\
\text { intensive care } \\
\text { unit (2 males) } \\
\text { Weight: } 61.1 \mathrm{~kg} \text {, } \\
59.0 \mathrm{~kg}\end{array}$ & $\begin{array}{l}\text { Development of a } \\
\text { new assay for } \\
\text { measuring total and } \\
\text { free concentrations of } \\
\text { daptomycin in } \\
\text { plasma with potential } \\
\text { clinical applications }\end{array}$ & $\begin{array}{c}\text { CLcr } \\
17.5 \mathrm{~mL} / \mathrm{min} \\
\mathrm{CLcr} \\
140.5 \mathrm{~mL} / \mathrm{min}\end{array}$ & $\begin{array}{c}\text {-every } 48 \mathrm{~h} \text { of } \\
350 \mathrm{mg} \\
\text { (CLcr }< \\
30 \mathrm{~mL} / \mathrm{min})- \\
\text { once-daily } \\
\text { dose of } \\
350 \mathrm{mg}(\mathrm{CLcr} \\
\geq 30 \mathrm{~mL} / \mathrm{min})\end{array}$ & $\begin{array}{c}\text { UPLC-MS / } \\
\text { MS }\end{array}$ & $\begin{array}{c}\text {-Concentration ranges: } \\
0.5-200 \mu \mathrm{g} / \mathrm{mL} \text { in total } \\
\text { daptomycin and } \\
0.04-40 \mu \mathrm{g} / \mathrm{mL} \text { in free } \\
\text { daptomycin-Recovery rate: } \\
\text { approximately } 100 \% \text { of free } \\
\text { daptomycin from ultrafiltration } \\
\text {-Limits of quantitation: } \\
0.5 \mu \mathrm{g} / \mathrm{mL} \text { (total daptomycin) } \\
\text { and } 0.04 \mu \mathrm{g} / \mathrm{mL} \text { (free } \\
\text { daptomycin) } \\
\text {-Recovery rate: total } \\
\text { daptomycin measurements } \\
\text { ranged from } 57.1 \text { to } 67.4 \% \text { and } \\
\text { free daptomycin measurements } \\
\text { ranged from } 54.6 \text { to } 62.3 \%\end{array}$ & $\begin{array}{c}\text {-Patient with low } \\
\text { renal function: Cmax } \\
\text { of free drug: } \\
2.85 \mu \mathrm{g} / \mathrm{mL} \text { (Day 3), } \\
4.2 \mu \mathrm{g} / \mathrm{mL} \text { (Day 5) } \\
\text { Ctrough of free drug: } \\
0.29 \mu \mathrm{g} / \mathrm{mL} \text { (Day 3), } \\
0.86 \mu \mathrm{g} / \mathrm{mL} \text { (Day 5) } \\
\text {-Patient with normal } \\
\text { renal function: } \\
\text { Median unbound } \\
\text { plasma: } \\
\text { Cmax of free drug: } \\
2.69 \mu \mathrm{g} / \mathrm{mL} \text { (Day 3), } \\
2.77 \mu \mathrm{g} / \mathrm{mL} \text { (Day 5) } \\
\text { Ctrough of free drug: } \\
0.77 \mu \mathrm{g} / \mathrm{mL} \text { (Day 3), } \\
0.34 \mu \mathrm{g} / \mathrm{mL} \text { (Day 5) }\end{array}$ & nd & [27] \\
\hline & $\begin{array}{c}\text { Population: } \\
n=53 \text { patients } \\
\text { Sex: Male } \\
(n=33), \text { female } \\
(n=19)\end{array}$ & $\begin{array}{c}\text { Examine serum } \\
\text { daptomycin levels, } \\
\text { creatinine } \\
\text { phosphokinase levels, } \\
\text { and the incidence of } \\
\text { other adverse effects }\end{array}$ & $\begin{array}{c}\text { CLcr } \geq \\
80 \mathrm{~mL} / \mathrm{min}: \\
n=15 \\
30 \leq \mathrm{CLcr}< \\
80 \mathrm{~mL} / \mathrm{min}: \\
n=23 \\
\text { CLcr }< \\
30 \mathrm{~mL} / \mathrm{min}: \\
n=14 \\
\text { haemodialysis: } \\
n=8\end{array}$ & $\begin{array}{c}4.0<\text { dose } \\
\leq 5.0 \mathrm{mg} / \mathrm{kg} \\
n=7 \\
5.0<\text { dose } \\
\leq 6.0 \mathrm{mg} / \mathrm{kg} \\
n=19 \\
6.0<\text { dose } \\
\leq 7.0 \mathrm{mg} / \mathrm{kg}: \\
n=17 \\
\leq 7.0 \mathrm{mg} / \mathrm{kg} \\
n=4\end{array}$ & HPLC-PDA & $\begin{array}{c}\text {-Response at the lowest } \\
\text { concentration }(3.5 \mu \mathrm{g} / \mathrm{mL}) \text { was } \\
\text { significantly more than } 5 \text { times } \\
\text { higher than that of the blank } \\
\text { serum } \\
\text {-Interday coefficient of } \\
\text { variation for the lowest and } \\
\text { highest concentration } \\
(200 \mu \mathrm{g} / \mathrm{mL}) \text { samples was } \\
\text { within } 15 \% \text {. }\end{array}$ & $\begin{array}{c}\text { Cmax: } \\
\text { 172.2-271.7 mg/L } \\
\text { (median = 249.6; } \\
n=6)\end{array}$ & nd & [28] \\
\hline
\end{tabular}


Table 1. Cont.

\begin{tabular}{|c|c|c|c|c|c|c|c|c|c|}
\hline Drug & Characteristics & Objective & Renal Function & Dose & $\begin{array}{l}\text { Measurement } \\
\text { System }\end{array}$ & Measurement Accuracy & $\begin{array}{c}\text { Blood } \\
\text { Concentration }\end{array}$ & $\begin{array}{c}\text { CSF } \\
\text { Concentration }\end{array}$ & Ref. \\
\hline \multirow{3}{*}{ LZD } & $\begin{array}{c}\text { Age: } 78 \\
\text { Sex: male } \\
\text { weight: } 48.2 \mathrm{~kg}\end{array}$ & $\begin{array}{c}\text { Treatment of } \\
\text { mediastinitis with } \\
\text { TDM of serum and } \\
\text { wound exudate } \\
\text { concentrations of } \\
\text { linezolid in renal } \\
\text { function impaired } \\
\text { patients. }\end{array}$ & $\begin{array}{l}\text { Scr: } 5.6 \mathrm{mg} / \mathrm{dL} \\
\text { glomerular } \\
\text { filtration rate: } \\
8.6 \mathrm{~mL} / \mathrm{min} / \\
1.73 \mathrm{~m}^{2}\end{array}$ & $\begin{array}{l}600 \mathrm{mg} \text { every } \\
24 \mathrm{~h} \\
\text { After that, } \\
300 \mathrm{mg} \text { every } \\
24 \mathrm{~h}\end{array}$ & HPLC & $\begin{array}{c}\text {-Lower limit: } 0.1 \mu \mathrm{g} / \mathrm{mL} \\
\text {-Intra/interday precision } \\
\text { below } 5.0 \%\end{array}$ & $\begin{array}{l}\text { Cmin: } 11.5 \mu \mathrm{g} / \mathrm{mL} \\
\text { (Day 21) } \\
\text { Cmin: } 5.5 \mu \mathrm{g} / \mathrm{mL} \\
\text { (Day 55) }\end{array}$ & nd & [29] \\
\hline & $\begin{array}{c}\text { Age: } 77 \\
\text { Sex: female } \\
\text { weight: } 55 \mathrm{~kg}\end{array}$ & $\begin{array}{c}\text { TDM was effective in } \\
\text { preventing } \\
\text { thrombocytopenia } \\
\text { with linezolid: } \\
\text { a case report }\end{array}$ & $\begin{array}{c}\text { CLcr } \\
29.9 \mathrm{~mL} / \mathrm{min}\end{array}$ & $\begin{array}{c}600 \mathrm{mg} \text { twice } \\
\text { a day } \\
\text { After that, } \\
600 \mathrm{mg} \text { every } \\
24 \mathrm{~h}\end{array}$ & HPLC & $\begin{array}{c}\text {-Lower limit: } 0.25 \mu \mathrm{g} / \mathrm{mL} \\
\text {-Intra/interday precision } \\
\text { below } 5.0 \%\end{array}$ & $39.4 \mu \mathrm{g} / \mathrm{mL}$ (Day 9) & nd & {$[30]$} \\
\hline & $\begin{array}{c}\text { Age: } 79 \\
\text { Sex: female } \\
\text { weight: } 58.5 \mathrm{~kg}\end{array}$ & $\begin{array}{l}\text { Successful } \\
\text { combination therapy } \\
\text { with linezolid and } \\
\text { rifampicin with } \\
\text { appropriate } \\
\text { management of } \\
\text { linezolid TDM in } \\
\text { MRSA osteomyelitis: } \\
\text { a case report }\end{array}$ & Scr $0.4 \mathrm{mg} / \mathrm{dL}$ & $\begin{array}{l}600 \text { mg twice } \\
\text { a day } \\
\text { Thereafter, } \\
300 \text { mg twice } \\
\text { a day } \\
\text { At the time } \\
\text { rifampicin is } \\
\text { combined, } \\
600 \text { mg twice } \\
\text { a day }\end{array}$ & HPLC & $\begin{array}{c}\text {-Lower limit: } 0.1 \mu \mathrm{g} / \mathrm{mL} \\
\text {-Intra/interday precision } \\
\text { below } 5.0 \%\end{array}$ & $\begin{array}{c}\text { Cmin: } 15.1 \mu \mathrm{g} / \mathrm{mL} \\
\text { (Day 5) Cmin: } \\
\text { 13.9 } \mu \mathrm{g} / \mathrm{mL} \text { (Day } 8) \\
\text { As a result of } \\
\text { combination therapy, } \\
\text { Cmin was in the } \\
\text { optimal range of } 3.7 \\
\text { to } 7.2 \mathrm{mg} / \mathrm{mL} \text {. }\end{array}$ & nd & {$[31]$} \\
\hline TZD & $\begin{array}{c}\text { Population: } \\
n=3 \text { patients }\end{array}$ & $\begin{array}{l}\text { Development of an } \\
\text { assay system for } \\
\text { simultaneous } \\
\text { quantification of } \\
\text { plasma } \\
\text { concentrations of } \\
\text { LZD, DAP, and TZD } \\
\text { and its clinical } \\
\text { application }\end{array}$ & $\begin{array}{c}\text { CLcr 48.3- } \\
64.5 \mathrm{~mL} / \mathrm{min}\end{array}$ & $\begin{array}{l}200 \text { mg once } \\
\text { daily }\end{array}$ & $\begin{array}{l}\text { UPLC- } \\
\text { MS/MS }\end{array}$ & $\begin{array}{c}\text {-TZD showed good linearity } \\
\text { over wide ranges of } \\
5-5000 \mathrm{ng} / \mathrm{mL} \text {. } \\
\text {-The lower limited of } \\
\text { quantification and three quality } \\
\text { controls (QCs: low, medium } \\
\text { and high) were less than } 15 \% \\
\text { for both accu-racy and } \\
\text { precision. } \\
\text {-Recovery rate of TZD: more } \\
\text { than } 84.8 \%\end{array}$ & $\begin{array}{l}\text { Cpeak and Cmin of } \\
\text { TZD ranged from } \\
1.87 \text { to } 4.92 \mu \mathrm{g} / \mathrm{mL} \\
\text { and from } 0.09 \text { to } \\
0.78 \mu \mathrm{g} / \mathrm{mL}\end{array}$ & nd & {$[32]$} \\
\hline
\end{tabular}


Table 1. Cont.

\begin{tabular}{|c|c|c|c|c|c|c|c|c|c|}
\hline Drug & Characteristics & Objective & Renal Function & Dose & $\begin{array}{l}\text { Measurement } \\
\text { System }\end{array}$ & Measurement Accuracy & $\begin{array}{c}\text { Blood } \\
\text { Concentration }\end{array}$ & $\begin{array}{c}\text { CSF } \\
\text { Concentration }\end{array}$ & Ref. \\
\hline & $\begin{array}{c}\text { Population: } \\
n=3 \text { patients }\end{array}$ & $\begin{array}{l}\text { Development of an } \\
\text { assay for } \\
\text { simultaneous } \\
\text { quantification of } \\
12 \text { antimicrobial } \\
\text { agents commonly } \\
\text { used in ICU and its } \\
\text { clinical application }\end{array}$ & $\begin{array}{l}\text { CLcr 51.7- } \\
60.4 \mathrm{~mL} / \mathrm{min}\end{array}$ & $\begin{array}{c}200 \mathrm{mg} \\
\text { once daily }\end{array}$ & $\begin{array}{l}\text { UHPLC- } \\
\text { MS/MS }\end{array}$ & $\begin{array}{c}\text { - The concentration ranges of } \\
\text { calibration curves for TZD was } \\
0.01-5 \mu \mathrm{g} / \mathrm{mL} \text {. } \\
\text {-The measured concentrations } \\
\text { in blanks were less than } 20 \% \text { of } \\
\text { the peak response of the lower } \\
\text { limited of quantification and } \\
\text { less than } 5 \% \text { for internal } \\
\text { standard }\end{array}$ & $\begin{array}{l}\text { The ranges of Cmin } \\
\text { and Cpeak in } \\
\text { patients with CLcr of } \\
51.7-60.4 \mathrm{~mL} / \mathrm{min} \\
\text { were } 0.06-0.12 \text { and } \\
2.67-4.01 \mu \mathrm{g} / \mathrm{mL}\end{array}$ & nd & [33] \\
\hline \multirow{2}{*}{ LZD } & $\begin{array}{c}\text { Age: } 78 \\
\text { Sex: male } \\
\text { weight: } 48.2 \mathrm{~kg}\end{array}$ & $\begin{array}{c}\text { Treatment of } \\
\text { mediastinitis with } \\
\text { TDM of serum and } \\
\text { wound exudate } \\
\text { concentrations of } \\
\text { linezolid in renal } \\
\text { function impaired } \\
\text { patients. }\end{array}$ & $\begin{array}{l}\text { Scr: } 5.6 \mathrm{mg} / \mathrm{dL} \\
\text { glomerular } \\
\text { filtration rate: } \\
8.6 \mathrm{~mL} / \mathrm{min} / \\
1.73 \mathrm{~m}^{2}\end{array}$ & $\begin{array}{c}600 \mathrm{mg} \text { every } \\
24 \mathrm{~h} \\
\text { After that, } \\
300 \mathrm{mg} \text { every } \\
24 \mathrm{~h}\end{array}$ & HPLC & $\begin{array}{c}\text {-Lower limit: } 0.1 \mu \mathrm{g} / \mathrm{mL} \\
\text {-Intra/interday precision } \\
\text { below } 5.0 \%\end{array}$ & $\begin{array}{c}\text { Cmin: } 11.5 \mu \mathrm{g} / \mathrm{mL} \\
\text { (Day 21) } \\
\text { Cmin: } 5.5 \mu \mathrm{g} / \mathrm{mL} \\
\text { (Day 55) }\end{array}$ & nd & [29] \\
\hline & $\begin{array}{c}\text { Age: } 79 \\
\text { Sex: female } \\
\text { weight: } 58.5 \mathrm{~kg}\end{array}$ & $\begin{array}{l}\text { Successful } \\
\text { combination therapy } \\
\text { with linezolid and } \\
\text { rifampicin with } \\
\text { appropriate } \\
\text { management of } \\
\text { linezolid TDM in } \\
\text { MRSA osteomyelitis: } \\
\text { a case report }\end{array}$ & Scr $0.4 \mathrm{mg} / \mathrm{dL}$ & $\begin{array}{l}600 \text { mg twice } \\
\text { a day } \\
\text { Thereafter, } \\
300 \text { mg twice } \\
\text { a day } \\
\text { At the time } \\
\text { rifampicin is } \\
\text { combined, } \\
600 \text { mg twice } \\
\text { a day }\end{array}$ & HPLC & $\begin{array}{c}\text {-Lower limit: } 0.1 \mu \mathrm{g} / \mathrm{mL} \\
\text {-Intra/interday precision } \\
\text { below } 5.0 \%\end{array}$ & $\begin{array}{c}\text { Cmin: } 15.1 \mu \mathrm{g} / \mathrm{mL} \\
\text { (Day } 5) \\
\text { Cmin: } 13.9 \mu \mathrm{g} / \mathrm{mL} \\
\text { (Day } 8) \\
\text { As a result of } \\
\text { combination therapy, } \\
\text { Cmin was in the } \\
\text { optimal range of } 3.7 \\
\text { to } 7.2 \mathrm{mg} / \mathrm{mL} \text {. }\end{array}$ & nd & [31] \\
\hline
\end{tabular}


Table 1. Cont.

\begin{tabular}{|c|c|c|c|c|c|c|c|c|c|}
\hline Drug & Characteristics & Objective & Renal Function & Dose & $\begin{array}{l}\text { Measurement } \\
\text { System }\end{array}$ & Measurement Accuracy & $\begin{array}{c}\text { Blood } \\
\text { Concentration }\end{array}$ & $\begin{array}{c}\text { CSF } \\
\text { Concentration }\end{array}$ & Ref. \\
\hline \multirow[t]{2}{*}{ TZD } & $\begin{array}{l}\text { Population: } \\
n=3 \text { patients }\end{array}$ & $\begin{array}{l}\text { Development of an } \\
\text { assay system for } \\
\text { simultaneous } \\
\text { quantification of } \\
\text { plasma } \\
\text { concentrations of } \\
\text { LZD, DAP, and TZD } \\
\text { and its clinical } \\
\text { application }\end{array}$ & $\begin{array}{l}\text { CLcr 48.3- } \\
64.5 \mathrm{~mL} / \mathrm{min}\end{array}$ & $\begin{array}{c}200 \mathrm{mg} \\
\text { once daily }\end{array}$ & $\begin{array}{l}\text { UPLC- } \\
\text { MS/MS }\end{array}$ & $\begin{array}{l}\text {-TZD showed good linearity } \\
\text { over wide ranges of } \\
5-5000 \mathrm{ng} / \mathrm{mL} \text {. } \\
\text {-The lower limited of } \\
\text { quantification and three quality } \\
\text { controls (QCs: low, medium } \\
\text { and high) were less than } 15 \% \\
\text { for both accu-racy and } \\
\text { precision. } \\
\text {-Recovery rate of TZD: more } \\
\text { than } 84.8 \%\end{array}$ & $\begin{array}{c}\text { Cpeak and Cmin of } \\
\text { TZD ranged from } \\
1.87 \text { to } 4.92 \mu \mathrm{g} / \mathrm{mL} \\
\text { and from } 0.09 \text { to } \\
0.78 \mu \mathrm{g} / \mathrm{mL}\end{array}$ & nd & {$[32]$} \\
\hline & $\begin{array}{l}\text { Population: } \\
n=3 \text { patients }\end{array}$ & $\begin{array}{c}\text { Development of an } \\
\text { assay for } \\
\text { simultaneous } \\
\text { quantification of } 12 \\
\text { antimicrobial agents } \\
\text { commonly used in } \\
\text { ICU and its clinical } \\
\text { application }\end{array}$ & $\begin{array}{l}\text { CLcr 51.7- } \\
60.4 \mathrm{~mL} / \mathrm{min}\end{array}$ & $\begin{array}{c}200 \mathrm{mg} \\
\text { once daily }\end{array}$ & $\begin{array}{l}\text { UHPLC- } \\
\text { MS/MS }\end{array}$ & $\begin{array}{c}\text {-The concentration ranges of } \\
\text { calibration curves for TZD was } \\
0.01-5 \mu \mathrm{g} / \mathrm{mL} \text {. } \\
\text {-The measured concentrations } \\
\text { in blanks were less than } 20 \% \text { of } \\
\text { the peak response of the lower } \\
\text { limited of quantification and } \\
\text { less than } 5 \% \text { for internal } \\
\text { standard }\end{array}$ & $\begin{array}{l}\text { The ranges of Cmin } \\
\text { and Cpeak in } \\
\text { patients with CLcr of } \\
51.7-60.4 \mathrm{~mL} / \mathrm{min} \\
\text { were } 0.06-0.12 \text { and } \\
2.67-4.01 \mu \mathrm{g} / \mathrm{mL}\end{array}$ & nd & [33] \\
\hline
\end{tabular}




\section{TDM of Daptomycin}

\subsection{Characteristics of Daptomycin and Significance of Blood Level Measurement}

DAP is a lipopeptide antibiotic that is effective against antibiotic-resistant Grampositive bacteria such as methicillin-resistant Staphylococcus aureus (MRSA) and vancomycinresistant enterococci (VRE) [34,35]. DAP has a molecular weight of about $1.6 \mathrm{kDa}$, a high protein-binding rate (90-95\%), and a distribution volume of $0.1 \mathrm{~L} / \mathrm{kg}$ [22]. The elimination half-life of DAP is approximately 8 to $9 \mathrm{~h}$ in adults [36]. Currently, TDM of DAP is not routinely performed in clinical practice in Japan. A once-daily dose of $4 \mathrm{mg} / \mathrm{kg}$ is administered for skin and soft tissue infections and $6 \mathrm{mg} / \mathrm{kg}$ for sepsis and infective endocarditis of the right heart system [37]. DAP has also been administered every $48 \mathrm{~h}$ in patients whose CLcr is less than $30 \mathrm{~mL} / \mathrm{min}$ or for those who require dialysis [38]. As this drug is mainly excreted by the kidneys, the dosage should be adjusted for patients with impaired renal function.

It has been reported that the efficacy of DAP is strongly correlated with the areaunder-the-curve/minimum inhibitory concentration (AUC/MIC) ratio and peak concentration/MIC (Cpeak/MIC) ratio [39], and it is considered to be drug concentration dependent. In clinical studies, an AUC/MIC of 666 or higher in MRSA infections was associated with a lower mortality [40], and a trough concentration of less than $3.18 \mu \mathrm{g} / \mathrm{mL}$ (steady state) was associated with poorer clinical outcomes [41]. A typical side effect of DAP is increased creatine phosphokinase (CPK) levels [42,43]. In particular, it is known that a blood level of $24.3 \mu \mathrm{g} / \mathrm{mL}$ or higher increases the risk of higher CPK levels [42]. On the other hand, safety and tolerability at high doses $(\geq 8 \mathrm{mg} / \mathrm{kg}$ ) have also been reported [44-46], and the correlation between elevated CPK levels and dosage and blood levels is not clear. Blood levels of DAP vary widely from patient to patient, and factors that may contribute to this variability include renal function, hemodialysis, continuous renal replacement therapy, obesity, hypoalbuminemia, and the pathogenesis of severe infections [41,47-50]. At this stage, there is insufficient evidence to conclusively determine a correlation between the efficacy and adverse effects of DAP and blood levels of the drug, and it is unclear whether TDM of DAP should be recommended for clinical practice in Japan.

\subsection{Report on the Measurement of Blood Levels of Daptomycin in Japan}

We present a report on the measurement of blood levels of DAP in clinical practice in Japan, and its application to the treatment of infectious diseases.

Urakami et al. [24] used Monte Carlo simulation and TDM to investigate the best way to manage DAP based on PK/PD parameters. Serum concentrations of DAP in 16 MRSAinfected patients were measured with the HPLC-UV system. First, venous blood (5 mL) was collected, and the blood sample was centrifuged at $5000 \times g$ for $10 \mathrm{~min}$ and stored at $-30{ }^{\circ} \mathrm{C}$ until plasma analysis. The lower limit of quantification for this assay was $0.78 \mu \mathrm{g} / \mathrm{mL}$. The analysis column was a TSK gel Octyl $-80 \mathrm{Ts}, 5 \mu, 250 \times 4.6 \mathrm{~mm}(\mathrm{TOSOH}$, Tokyo, Japan), UV wavelength was $214 \mathrm{~nm}$, and the mobile phase was $40 \mathrm{mM}$ phosphate ammonium buffer ( $\mathrm{pH} 4.5) /$ acetonitrile $=60: 40 v / v$. All of the solvents used were HPLC grade [24].

As a DAP pharmacokinetics parameter, the volume of distribution of patients in the study was larger than the volume of distribution among healthy Japanese subjects. The halflife of this drug was 8.9 to $34.9 \mathrm{~h}$, which gradually increased as CLcr decreased. In the Monte Carlo simulation, the cumulative fraction of response (CFR) for Cpeak/MIC $\geq 60$ [39] and AUC $/ \mathrm{MIC} \geq 666$ at $6 \mathrm{mg} / \mathrm{kg}$ every $24 \mathrm{~h}$ was $72.0 \%$ and $78.8 \%$, respectively, whereas at $10 \mathrm{mg} / \mathrm{kg}$ every $24 \mathrm{~h}$, both CFR values improved to $99 \%$. With TDM of DAP at $6 \mathrm{mg} / \mathrm{kg}$ every $24 \mathrm{~h}$, the target peak and AUC were reached in $40 \%$ of patients ( 2 of 5 ). In that study, they reported that TDM is necessary because of individual differences in PK with DAP. A high-dose regimen of $8 \mathrm{mg} / \mathrm{kg}$ or higher may be required to ensure efficacy, especially in Japanese patients with normal renal function. In this study, one patient with a trough level of $49.4 \mu \mathrm{g} / \mathrm{mL}$ and CLcr of $22.4 \mathrm{~mL} / \mathrm{min}$ had elevated CPK, but no other patients had adverse events attributable to DAP. 
Yamada et al. [25] investigated the relationship between DAP trough concentration (Cmin) and CPK elevation to determine the optimal DAP administration. DAP concentrations in the plasma of 20 patients were measured. Plasma samples were collected at trough and Cpeak within 60 min after the end of infusion on day 3 after DAP administration. HPLC analysis was coupled with use of a UV detector set to a detection wavelength of $214 \mathrm{~nm}$. The column used was Octyl-80Ts $(4.6 \times 250 \mathrm{~mm})$, temperature was $37^{\circ} \mathrm{C}$, the mobile phase was acetonitrile/ammonium phosphate buffer (40 mM, pH 4) (40:60), and flow rate was $1.5 \mathrm{~mL} / \mathrm{min}$. The lower limit of quantification for HPLC was $1.0 \mu \mathrm{g} / \mathrm{mL}$, and the intra- and inter-day coefficients of variation were less than $5.0 \%$. Logistic regression analysis was performed, and the Cmin of DAP was significantly associated with elevated CPK and was concentration dependent (odds ratio 1.21, $p=0.048$ ). Patients with DAP Cmin $<19.5 \mu \mathrm{g} / \mathrm{mL}$ did not show increased CPK, but those with Cmin $>19.5 \mu \mathrm{g} / \mathrm{mL}$ had a high rate of increased CPK $(4 / 5,80 \%)$, and three of these patients showed increased CPK after one week of treatment. Based on the results of the Monte Carlo simulation to determine the optimal dose of DAP, the estimated doses were 4-6 mg/ $\mathrm{kg} /$ day when the $\mathrm{MIC}$ was $0.5 \mu \mathrm{g} / \mathrm{mL}$ or less and $10 \mathrm{mg} / \mathrm{kg} /$ day when the MIC was $1 \mu \mathrm{g} / \mathrm{mL}$.

In addition to the above reports, the use of liquid chromatography-tandem mass spectrometry (LC-MS/MS) [26], ultra-performance liquid chromatography coupled to tandem mass spectrometry (UPLC-MS/MS) [27], and HPLC equipped with a photodiode array (UHPLC-PDA) [28] was also studied.

Based on the above reports, the clinical significance of TDM of DAP is considered to be significant, especially in patients with impaired renal function, hemodialysis, continuous renal replacement therapy, and obesity, because of the large variation in blood levels among patients. It is also expected to avoid the risk of elevated CPK and the emergence of resistant bacteria. However, there are limited data to support the use of TDM in DAP.

\section{TDM of Linezolid}

\subsection{Characteristics of Linezolid and Significance of Blood Level Measurement}

LZD is an oxazolidinone drug that has an excellent antibacterial activity against Grampositive bacteria, including MRSA and VRE [51,52]. The plasma protein-binding rate and volume of LZD distribution in adults are 31\% and 40-50 L, respectively [53]. Myelosuppression, including anemia and thrombocytopenia, has been reported as a serious side effect of LZD, and is generally reversible when discontinuing treatment, with recovery usually taking 1-2 weeks [54]. LZD does not require dosage adjustment with or without renal dysfunction $[55,56]$. The PK/PD parameter is the percentage of time that the plasma concentration exceeds the MIC (\% T > MIC) by more than $85 \%$, and the AUC/MIC ratio is 80-120 [57,58]. In terms of thrombocytopenia, the recommended range of trough concentrations for LZD is $2.0-7.0 \mu \mathrm{g} / \mathrm{mL}$ [59]. Patients with impaired renal function may have significantly lower platelet counts than those with normal renal function, and there are reports of therapeutic outcomes with TDM of LZD [60-62].

\subsection{Report on the Measurement of Blood Levels of Linezolid in Japan}

There are case reports of successful treatment of infection when Japanese hospital pharmacists performed TDM of LZD.

Tsuji et al. [29] investigated mediastinitis after cardiac surgery that was caused by MRSA in a patient with renal dysfunction by measuring trough concentrations in serum and wound exudate to adjust the LZD dose. As the patient's serum creatinine level and glomerular filtration rate were $5.6 \mathrm{mg} / \mathrm{dL}$ and $8.6 \mathrm{~mL} / \mathrm{min} / 1.73 \mathrm{~m}^{2}$, respectively, LZD was administered at a single dose of $600 \mathrm{mg}$ daily. On the 21st day of therapy, the serum Cmin was $11.5 \mu \mathrm{g} / \mathrm{mL}$ and the platelet count decreased to $65,000 / \mu \mathrm{L}$. The cessation of LZD administration for one day made the Cmin decrease to $3.5 \mu \mathrm{g} / \mathrm{mL}$ on the 23rd day. Although linezolid therapy restarted on the day 24th day, the Cmin increased to $9.3 \mu \mathrm{g} / \mathrm{mL}$ on the 27th day. Thus, the patient was administered a single dose of $300 \mathrm{mg}$ daily. As a 
result, the Cmin was maintained between 2 and $7 \mu \mathrm{g} / \mathrm{mL}$ and the platelet count recovered. Moreover, there was little decrease in efficacy with the change in dosage.

Next, Matsuda et al. [30] reported that two patients were cured with good control of the platelet count through the adjustment of LZD dosage by TDM. One patient who diagnosed pyogenic spondylitis caused by MRSA was administered $600 \mathrm{mg}$ twice daily. The patient's serum creatinine level was $1.37 \mathrm{mg} / \mathrm{dL}$. The platelet count started to decrease from the next day of therapy and to $94,000 / \mu \mathrm{L}$ on the 9th day of therapy. The Cmin was $39.4 \mu \mathrm{g} / \mathrm{mL}$, and therefore the patient was administered a single dose of $600 \mathrm{mg}$ daily. On the next day of the dose reduction, the Cmin was $35.1 \mu \mathrm{g} / \mathrm{mL}$, and the platelet count continued to decrease to $65,000 / \mu \mathrm{L}$. Fortunately, as MRSA was not detected from abscess culture, LZD administration was discontinued. However, the platelet reduction continued for three days after discontinuing LZD administration and the nadir of platelet count was $28,000 / \mu \mathrm{L}$. Another who had MRSA detected from the from abscess culture was administered $600 \mathrm{mg}$ twice daily. The patient's serum creatinine level was $0.75 \mathrm{mg} / \mathrm{dL}$. The Cmin was $22.3 \mu \mathrm{g} / \mathrm{mL}$ on the 2nd day of therapy, and then the dosage of LZD was decreased to $600 \mathrm{mg}$ once daily. The patient completed the treatment of LZD for 28 days without thrombocytopenia. The measurement of Cmin early after LZD administration could lead long-term administration with tolerance for thrombocytopenia.

Ashizawa et al. [31] performed TDM of LZD for patients treated with a combination of LZD and rifampicin (RFP) for osteomyelitis caused by MRSA. The concomitant use of LZD and RFP may decrease the serum concentration of linezolid due to drug interactions, which may reduce the therapeutic effect [59]. The patient was treated with a dose of LZD $600 \mathrm{mg}$ twice daily and a dose of RFP $450 \mathrm{mg}$ once daily, and the Cmin was maintained within an optimal range of 3.7-7.3 $\mu \mathrm{g} / \mathrm{mL}$. They concluded that TDM could be useful for keeping the efficacy and safety of combination therapy with LZD and RFP.

These reports suggest that TDM should be considered in terms of tolerability, especially in conditions that require long-term administration of LZD, such as osteomyelitis and meningitis of MRSA.

\section{TDM of Tedizolid}

\subsection{Characteristics of Tedizolid and Significance of Blood Level Measurement}

TZD phosphate is a novel oxazolidinone pro-drug that is converted to TZD by endogenous phosphatases [63,64]. TZD has s microbiologic activity against a broad range of Gram-positive pathogens, including resistant strains such as MRSA and VRE $[65,66]$. The profile of TDZ is roughly similar to LZD, which is the first commercialized oxazolidinone antibiotic. The dose of TZD does not need to be modified in patients with renal impairment or on hemodialysis. Due to the absorptive bioavailability with over $80 \%$, TZD is administered both orally and intravenously $[67,68]$, the time to maximum concentration is achieved within approximately $3 \mathrm{~h}$ of oral dosing, and steady-state plasma concentrations are reached within 3 days of the initial daily dose $[69,70]$. Moreover, TZD shows moderately protein bound with over $80 \%$ in human plasma and is well distributed into tissue where unbound concentrations are almost equal to the free concentrations in the plasma [71]. The PK parameters and penetration of adipose tissue and muscle of TZD following the single oral administration of $200 \mathrm{mg}$ and pulmonary of TZD following the oral administration of $200 \mathrm{mg}$ once daily are shown in Table 2 . The mean $\mathrm{AUC}_{0-12}$ values for adipose tissue and muscle were 5.3 and $5.9 \mathrm{mg} \mathrm{h} / \mathrm{L}$, respectively. The mean rates of penetration into the adipose tissue and muscle using the $\mathrm{AUC}_{0-12}$ in the plasma were 1.1 and 1.2 , respectively [70]. The estimated $\mathrm{AUC}_{0-24}$ value for the pulmonary was $106.0 \mathrm{mg} \mathrm{h} / \mathrm{L}$. The rate of the $\mathrm{AUC}_{0-24}$ in the pulmonary over the $\mathrm{AUC}_{0-24}$ in the plasma was 39.7 [71]. 
Table 2. Pharmacokinetic parameters and penetration of each tissue.

\begin{tabular}{|c|c|c|c|}
\hline & Skin and Soft Tissue & & Intrapulmonary \\
\hline & Adipose Tissue & Muscle & ELT \\
\hline $\mathrm{AUC}_{0-12}$ & 5.3 & 5.9 & NR \\
\hline $\mathrm{AUC}_{0-24}$ & NR & NR & 106.0 \\
\hline $\mathrm{AUC}_{\text {tissue }} / \mathrm{AUC}_{\text {plasma }}$ & 1.1 & 1.2 & 39.7 \\
\hline
\end{tabular}

On the other hand, administration is once per day as TZD shows a long elimination half-life of $12 \mathrm{~h}$. The PK profile was similar after single and multiple daily doses because of a linear PK [72]. The mean AUC was $30 \mathrm{mg} \mathrm{h} / \mathrm{L}$, the mean maximum plasma concentration was $2.6 \mu \mathrm{g} / \mathrm{mL}$, and the mean elimination half-life was $11 \mathrm{~h}$ after a single intravenous $200 \mathrm{mg}$ dose [69]. TZD is primarily metabolized by the liver, and only $18 \%$ of the administered drug is eliminated in the urine [73]. The PK/PD index that best correlates with efficacy is the free drug AUC/MIC (fAUC/MIC). The target fAUC/MIC required for antimicrobial efficacy was over 3 [74].

To date, there is no available information on TDM of TZD and dosing optimization. However, it has been reported that the AUC depending on body weight shows individual difference and that thrombocytopenia caused by TZD depends on dose [75,76]. Moreover, a recent report on clinical application of measuring the concentrations showed an approximately eight-fold difference in a trough concentration between patient with a CLcr of $64.5 \mathrm{~mL} / \mathrm{min}$ and that of $50.2 \mathrm{~mL} / \mathrm{min}$ [32]. In the future, measuring the TZD concentrations in clinical settings might be needed.

\subsection{Report on the Measurement of Blood Levels of Tedizolid in Japan}

Several methods for the quantification of TZD in plasma using HPLC have been reported [69-71,77-83]. In Japan, three reports were published in 2020-2021.

Kai et al. reported the quantification in plasma samples from three patients in the intensive care unit (ICU) using ultra-high-performance liquid chromatography coupled with tandem mass spectrometry (UHPLC-MS/MS) [33]. The concentration range of calibration curves for TZD was $0.01-5 \mu \mathrm{g} / \mathrm{mL}$. The measured concentrations in blanks were less than $20 \%$ of the peak response of the lower limited of quantification (LLOQ) and less than $5 \%$ for internal standard (IS). Blood samples were collected before infusion (Cmin) and $1 \mathrm{~h}$ after infusion for TZD (Cpeak). The ranges of Cmin and Cpeak in patients with CLcr of 51.7-60.4 mL/min were 0.06-0.12 and $2.67-4.01 \mu \mathrm{g} / \mathrm{mL}$. Next, Tanaka et al. reported the quantification in plasma samples using ultra-performance liquid chromatography coupled with MC/MC (UPLC-MS/MS) [32]. The regression coefficients of the actual concentration versus back-calculated concentration was over 0.99 for a range from 0.005 to $5 \mu \mathrm{g} / \mathrm{mL}$, which showed the linearity. The LLOQ and three quality controls (QCs of low, medium, and high) were less than $15 \%$ for both accuracy and precision. Two patients received intravenous infusion of TZD at a dose of $200 \mathrm{mg}$ once daily during the ICU admission. Blood sampling was conducted as Cpeak at $1 \mathrm{~h}$ after the initiation of infusion and as $\mathrm{Cmin}$ just prior to the infusion of TZD. The measured Cpeak and Cmin of TZD ranged from 1.87 to $4.92 \mu \mathrm{g} / \mathrm{mL}$ and from 0.09 to $0.78 \mu \mathrm{g} / \mathrm{mL}$, with remarkable individual differences between ICU patients with the CLcr of 50.2 and $64.5 \mathrm{~mL} / \mathrm{min}$. It took a short run time of 5 min per sample, which allowed for a relatively rapid feedback of the results to physicians. Considering these individual differences and the promptness of measurement, TDM of TZD would be required for ICU patients as a first target population.

Finally, Tsuji et al. reported the quantification of serum TZD concentrations using high-performance liquid chromatography-fluorescence (HPLC-FL) [84]. High linearity with $\mathrm{R}^{2}>0.999$ was exhibited over a concentration range from 0.025 to $10 \mu \mathrm{g} / \mathrm{mL}$ for TZD. The range of intra- and inter-assay accuracies of TZD were from $99.2 \%$ to $107.0 \%$ and from $99.2 \%$ to $107.7 \%$, respectively. The range of intra-and inter-assay precisions were from 
$0.5 \%$ to $3.2 \%$ and from $0.3 \%$ to $4.1 \%$, respectively. The intra- and inter-assay precisions for the LLOQ were $17.0 \%$ and $15.3 \%$, respectively. This method has wider ranges of the TZD concentrations than the two studies [32,33]. However, the measurement of TZD concentration in actual patients receiving TZD has not been conducted yet.

At this time, as far as we have been able to determine, we have not found anything definitive on the clinical significance of TDM of TZD.

\section{The States of TDM for DAP, LZD, and TZD in Other Countries}

Several studies have highlighted the importance of TDM to optimize daptomycin use [41]. Nevertheless, there is no recommendation for TDM in any of the current guidelines for daptomycin, and we were not able to find studies reporting the TDM practice in other countries. Recently, a questionnaire survey regarding institutional TDM practice for antibiotics for all Australian hospitals was conducted [85]. TDM for linezolid was less common, with only $5 \%$. Moreover, daptomycin and tedizolid were not even listed in the question. In particular, the role of TDM for tedizolid [86] and daptomycin remains to be proven.

\section{Limitation}

In Japan, to the best of our knowledge, some, but not all, hospitals and clinics have bioanalytical methods validated following the guidelines of the Food and Drug Administration, the European Medicines Agency, and the Japanese regulatory authorities when conducting TDM. This process is very time-consuming. Therefore, it is not practical to validate methods on a limited number of patients. As the number of drugs covered by insurance increases, the need for simpler and faster bioanalytical methods increases. In addition, the validation of standard bioanalytical methods is very costly. In Japan, many facilities cannot perform bioanalytical methods on time, making it challenging to perform TDM of these antibiotics frequently. In Japan, many facilities lack access to the timely bioanalytical method, and most facilities, including universities and laboratories, use research funds to conduct them.

\section{Conclusions}

This paper discusses the need for TDM of antibiotics for which TDM cannot be billed to insurance in Japan, and the reporting of facilities that implement it. TDM, which used to be performed in the laboratory, has shifted to bedside TDM by hospital pharmacists. Therefore, there is a need to build a measurement system that can quickly obtain the results of the drug concentrations. It is expected that pharmacists will be able to use the results of such measurements in real-time at medical sites to help design dosages. As mentioned, some facilities measure the concentration of drugs that cannot be billed for medical treatment at their own facilities, but the number is still tiny. To expand the number of drugs subject to TDM that can be billed to insurance, it is essential to build evidence. In order to build evidence supporting the use of TDM, it is necessary to establish methods for measuring drugs, introduce analytical equipment, and enhance medical staff with expertise. It is desirable to establish a system in which pharmaceutical universities and medical institutions, which are well equipped with these facilities, work together to build evidence for recommending TDM.

Author Contributions: Conceptualization, F.E. and Y.H.; writing—original draft preparation, F.E., Y.H., H.K., T.M. and T.K.; writing-review and editing, F.E., Y.H., H.K., T.M. and T.K. All authors have read and agreed to the published version of the manuscript.

Funding: This research received no external funding.

Institutional Review Board Statement: Not applicable.

Informed Consent Statement: Not applicable.

Data Availability Statement: All data are applicable in the paper. 
Conflicts of Interest: The authors declare no conflict of interest.

\section{References}

1. Morikawa, G.; Sorimachi, M.; Tamura, K.; Moriiwa, Y.; Shoji, A.; Okazawa, K.; Yanagida, A. Development of a practical HPLC system for in-hospital analysis of blood concentration of various medicines. Bunseki Kagaku 2019, 68, 473-481. [CrossRef]

2. Saito, T.; Tominaga, A.; Nozawa, M.; Unei, H.; Hatano, Y.; Fujita, Y.; Iseki, K.; Hori, Y. Committee on Toxicology Laboratories; Japanese Society for Clinical Toxicology [Survey of analytical works for drugs at emergency and critical care centers with high-performance instruments provided by the Ministry of Health and Welfare (at present: Ministry of Health, Labour, and Welfare) in fiscal 1998-Continuation of survey with 2008 survey results as point of reference]. Chudoku Kenkyu 2013, 26, 226-233. [PubMed]

3. Otani, N.; Hifumi, T.; Kitamoto, T.; Kobayashi, K.; Nakaya, N.; Tomioka, J. Current State of Drug Analysis in Japanese Emergency Departments: A Nationwide Survey. Acute Med. Surg. 2020, 7, e566. [CrossRef] [PubMed]

4. Practice Guidelines for Therapeutic Drug Monitoring of Antimicrobials in 2022. (Executive Summary)-the Japanese Society of Chemotherapy and the Japanese Society of Therapeutic Drug Monitoring. Available online: http://www.chemotherapy.or.jp/ guideline/tdm2022.html (accessed on 16 February 2022).

5. Klein, N.C.; Cunha, B.A. Third-Generation Cephalosporins. Med. Clin. N. Am. 1995, 79, 705-719. [CrossRef]

6. Aronoff, G.R.; Bennett, W.M.; Berns, J.S.; Brier, M.E.; Kasbekar, N.; Mueller, B.A.; Pasko, D.A.; Smoyer, W.E. Drug Prescribing in Renal Failure: Dosing Guidelines for Adults and Children, 5th ed.; American College of Physicians: Philadelphia, PA, USA, 2007; p. 153.

7. Patel, I.H.; Sugihara, J.G.; Weinfeld, R.E.; Wong, E.G.; Siemsen, A.W.; Berman, S.J. Ceftriaxone Pharmacokinetics in Patients with Various Degrees of Renal Impairment. Antimicrob. Agents Chemother. 1984, 25, 438-442. [CrossRef]

8. Bhattacharyya, S.; Darby, R.R.; Raibagkar, P.; Gonzalez Castro, L.N.; Berkowitz, A.L. Antibiotic-Associated Encephalopathy. Neurology 2016, 86, 963-971. [CrossRef]

9. Lamoth, F.; Buclin, T.; Pascual, A.; Vora, S.; Bolay, S.; Decosterd, L.A.; Calandra, T.; Marchetti, O. High Cefepime Plasma Concentrations and Neurological Toxicity in Febrile Neutropenic Patients with Mild Impairment of Renal Function. Antimicrob. Agents Chemother. 2010, 54, 4360-4367. [CrossRef]

10. Durand-Maugard, C.; Lemaire-Hurtel, A.-S.; Gras-Champel, V.; Hary, L.; Maizel, J.; Prud’homme-Bernardy, A.; Andréjak, C.; Andréjak, M. Blood and CSF Monitoring of Cefepime-Induced Neurotoxicity: Nine Case Reports. J. Antimicrob. Chemother. 2012, 67, 1297-1299. [CrossRef]

11. Rhodes, N.J.; Kuti, J.L.; Nicolau, D.P.; Neely, M.N.; Nicasio, A.M.; Scheetz, M.H. An Exploratory Analysis of the Ability of a Cefepime Trough Concentration Greater than $22 \mathrm{Mg} / \mathrm{L}$ to Predict Neurotoxicity. J. Infect. Chemother. 2016, 22, 78-83. [CrossRef]

12. Lacroix, C.; Kheloufi, F.; Montastruc, F.; Bennis, Y.; Pizzoglio, V.; Micallef, J. Serious Central Nervous System Side Effects of Cephalosporins: A National Analysis of Serious Reports Registered in the French Pharmacovigilance Database. J. Neurol. Sci. 2019, 398, 196-201. [CrossRef]

13. Kim, K.B.; Kim, S.M.; Park, W.; Kim, J.S.; Kwon, S.K.; Kim, H.-Y. Ceftiaxone-Induced Neurotoxicity: Case Report, Pharmacokinetic Considerations, and Literature Review. J. Korean Med. Sci. 2012, 27, 1120-1123. [CrossRef] [PubMed]

14. Yokoyama, Y.; Hosokawa, N.; Kudo, T.; Goda, H.; Ito, K.; Suzuki, M.; Funakoshi, R. Chorea-like Symptoms and High Blood Concentration of Ceftriaxone in a Patient Undergoing Hemodialysis: A Case Report. J. Infect. Chemother. 2020, 26, 285-288. [CrossRef] [PubMed]

15. Inoue, Y.; Doi, Y.; Arisato, T.; Sugioka, S.; Koga, K.; Nishioka, K.; Sugawara, A. Three Cases of Hemodialysis Patients Receiving High-Dose Ceftriaxone: Serum Concentrations and Its Neurotoxicity. Kidney Int. Rep. 2017, 2, 984-987. [CrossRef] [PubMed]

16. Lacroix, C.; Bera-Jonville, A.-P.; Montastruc, F.; Velly, L.; Micallef, J.; Guilhaumou, R. Serious Neurological Adverse Events of Ceftriaxone. Antibiotics 2021, 10, 540. [CrossRef] [PubMed]

17. AMR Clinical Reference Center. Surveillance of Antibiotic Sales in Japan. Available online: https://amrcrc.ncgm.go.jp/ surveillance/020/salestableDDD2017_2021.4.xlsx (accessed on 18 December 2021).

18. Kotani, A.; Hirai, J.; Hamada, Y.; Fujita, J.; Hakamata, H. Determination of Ceftriaxone Concentration in Human Cerebrospinal Fluid by High-Performance Liquid Chromatography with UV Detection. J. Chromatogr. B Anal. Technol. Biomed. Life Sci. 2019, 1124, 161-164. [CrossRef] [PubMed]

19. Oda, K. Development of Software for Antimicrobial PK/PD Simulation Incorporating Montecarlo Simulation Based on Microsoft ${ }^{\circledR}$ Office Excel. Iryo Yakugaku 2011, 37, 335-344. [CrossRef]

20. Suzuki, S.; Naito, S.; Numasawa, Y.; Asada, M.; Shoji, N.; Zeniya, M.; Takahashi, D.; Sato, H.; Iimori, S.; Nomura, N.; et al. Encephalopathy Induced by High Plasma and Cerebrospinal Fluid Ceftriaxone Concentrations in a Hemodialysis Patient. Intern. Med. 2019, 58, 1775-1779. [CrossRef]

21. Allegra, S.; Cardellino, C.S.; Fatiguso, G.; Cusato, J.; De Nicolò, A.; Avataneo, V.; Bonora, S.; D'Avolio, A.; Di Perri, G.; Calcagno, A. Effect of ABCC2 and ABCG2 Gene Polymorphisms and CSF-to-Serum Albumin Ratio on Ceftriaxone Plasma and Cerebrospinal Fluid Concentrations. J. Clin. Pharmacol. 2018, 58, 1550-1556. [CrossRef]

22. Le Turnier, P.; Grégoire, M.; Garot, D.; Guimard, T.; Duval, X.; Bernard, L.; Boutoille, D.; Dailly, É.; Navas, D.; Asseray, N. CSF Concentration of Ceftriaxone Following High-Dose Administration: Pharmacological Data from Two French Cohorts. J. Antimicrob. Chemother. 2019, 74, 1753-1755. [CrossRef] 
23. Nau, R.; Prange, H.W.; Muth, P.; Mahr, G.; Menck, S.; Kolenda, H.; Sörgel, F. Passage of Cefotaxime and Ceftriaxone into Cerebrospinal Fluid of Patients with Uninflamed Meninges. Antimicrob. Agents Chemother. 1993, 37, 1518-1524. [CrossRef]

24. Urakami, T.; Hamada, Y.; Oka, Y.; Okinaka, T.; Yamakuchi, H.; Magarifuchi, H.; Aoki, Y. Clinical Pharmacokinetic and Pharmacodynamic Analysis of Daptomycin and the Necessity of High-Dose Regimen in Japanese Adult Patients. J. Infect. Chemother. 2019, 25, 437-443. [CrossRef] [PubMed]

25. Yamada, T.; Ooi, Y.; Oda, K.; Shibata, Y.; Kawanishi, F.; Suzuki, K.; Nishihara, M.; Nakano, T.; Yoshida, M.; Uchida, T.; et al. Observational Study to Determine the Optimal Dose of Daptomycin Based on Pharmacokinetic/Pharmacodynamic Analysis. J. Infect. Chemother. 2020, 26, 379-384. [CrossRef] [PubMed]

26. Miyadera, Y.; Naito, T.; Yamada, T.; Kawakami, J. Simple LC-MS/MS Methods Using Core-Shell Octadecylsilyl Microparticulate for the Quantitation of Total and Free Daptomycin in Human Plasma. Ther. Drug Monit. 2018, 40, 589-595. [CrossRef] [PubMed]

27. Tanaka, R.; Suzuki, Y.; Goto, K.; Yasuda, N.; Koga, H.; Kai, S.; Ohchi, Y.; Sato, Y.; Kitano, T.; Itoh, H. Development and Validation of Sensitive and Selective Quantification of Total and Free Daptomycin in Human Plasma Using Ultra-Performance Liquid Chromatography Coupled to Tandem Mass Spectrometry. J. Pharm. Biomed. Anal. 2019, 165, 56-64. [CrossRef]

28. Ando, M.; Nishioka, H.; Nakasako, S.; Kuramoto, E.; Ikemura, M.; Kamei, H.; Sono, Y.; Sugioka, N.; Fukushima, S.; Hashida, T. Observational Retrospective Single-Centre Study in Japan to Assess the Clinical Significance of Serum Daptomycin Levels in Creatinine Phosphokinase Elevation. J. Clin. Pharm. Ther. 2020, 45, 290-297. [CrossRef]

29. Tsuji, Y.; Tashiro, M.; Ashizawa, N.; Ota, Y.; Obi, H.; Nagura, S.; Narukawa, M.; Fukahara, K.; Yoshimura, N.; To, H.; et al. Treatment of Mediastinitis Due to Methicillin-Resistant Staphylococcus Aureus in a Renal Dysfunction Patient Undergoing Adjustments to the Linezolid Dose. Intern. Med. 2015, 54, 235-239. [CrossRef]

30. Matsuda, S.; Kimura, R.; Izumi, K.; Noguchi, A.; Imazu, T.; Kugaya, Y.; Shimokawa, F.; Maeda, Y. Two Cases for Prevention of Linezolid-Induced Thrombocytopenia by Therapeutic Drug Monitoring. J. Jpn. Soc. Hosp. Pharm. 2019, 55, $423-427$.

31. Ashizawa, N.; Tsuji, Y.; Kawago, K.; Higashi, Y.; Tashiro, M.; Nogami, M.; Gejo, R.; Narukawa, M.; Kimura, T.; Yamamoto, Y. Successful Treatment of Methicillin-Resistant Staphylococcus Aureus Osteomyelitis with Combination Therapy Using Linezolid and Rifampicin under Therapeutic Drug Monitoring. J. Infect. Chemother. 2016, 22, 331-334. [CrossRef]

32. Tanaka, R.; Kai, M.; Goto, K.; Ohchi, Y.; Yasuda, N.; Tatsuta, R.; Kitano, T.; Itoh, H. High-Throughput and Wide-Range Simultaneous Determination of Linezolid, Daptomycin and Tedizolid in Human Plasma Using Ultra-Performance Liquid Chromatography Coupled to Tandem Mass Spectrometry. J. Pharm. Biomed. Anal. 2021, 194, 113764. [CrossRef]

33. Kai, M.; Tanaka, R.; Suzuki, Y.; Goto, K.; Ohchi, Y.; Yasuda, N.; Tatsuta, R.; Kitano, T.; Itoh, H. Simultaneous Quantification of Plasma Levels of 12 Antimicrobial Agents Including Carbapenem, Anti-Methicillin-Resistant Staphylococcus Aureus Agent, Quinolone and Azole Used in Intensive Care Unit Using UHPLC-MS/MS Method. Clin. Biochem. 2021, 90, 40-49. [CrossRef]

34. Wootton, M.; MacGowan, A.P.; Walsh, T.R. Comparative Bactericidal Activities of Daptomycin and Vancomycin against Glycopeptide-Intermediate Staphylococcus Aureus (GISA) and Heterogeneous GISA Isolates. Antimicrob. Agents Chemother. 2006, 50, 4195-4197. [CrossRef] [PubMed]

35. Dandekar, P.K.; Tessier, P.R.; Williams, P.; Nightingale, C.H.; Nicolau, D.P. Pharmacodynamic Profile of Daptomycin against Enterococcus Species and Methicillin-Resistant Staphylococcus Aureus in a Murine Thigh Infection Model. J. Antimicrob. Chemother. 2003, 52, 405-411. [CrossRef] [PubMed]

36. Dvorchik, B.H.; Brazier, D.; DeBruin, M.F.; Arbeit, R.D. Daptomycin Pharmacokinetics and Safety Following Administration of Escalating Doses Once Daily to Healthy Subjects. Antimicrob. Agents Chemother. 2003, 47, 1318-1323. [CrossRef]

37. Cubist Pharmaceuticals. Cubicin Package Insert; Cubist Pharmaceuticals: Lexington, MA, USA, 2003.

38. Hawkey, P.M. Pre-Clinical Experience with Daptomycin. J. Antimicrob. Chemother. 2008, 62 (Suppl. 3), iii7-iii14. [CrossRef] [PubMed]

39. Safdar, N.; Andes, D.; Craig, W.A. In Vivo Pharmacodynamic Activity of Daptomycin. Antimicrob. Agents Chemother. 2004, 48, 63-68. [CrossRef] [PubMed]

40. Falcone, M.; Russo, A.; Cassetta, M.I.; Lappa, A.; Tritapepe, L.; d'Ettorre, G.; Fallani, S.; Novelli, A.; Venditti, M. Variability of Pharmacokinetic Parameters in Patients Receiving Different Dosages of Daptomycin: Is Therapeutic Drug Monitoring Necessary? J. Infect. Chemother. 2013, 19, 732-739. [CrossRef]

41. Galar, A.; Muñoz, P.; Valerio, M.; Cercenado, E.; García-González, X.; Burillo, A.; Sánchez-Somolinos, M.; Juárez, M.; Verde, E.; Bouza, E. Current Use of Daptomycin and Systematic Therapeutic Drug Monitoring: Clinical Experience in a Tertiary Care Institution. Int. J. Antimicrob. Agents 2019, 53, 40-48. [CrossRef]

42. Bhavnani, S.M.; Rubino, C.M.; Ambrose, P.G.; Drusano, G.L. Daptomycin Exposure and the Probability of Elevations in the Creatine Phosphokinase Level: Data from a Randomized Trial of Patients with Bacteremia and Endocarditis. Clin. Infect. Dis. 2010, 50, 1568-1574. [CrossRef]

43. Kazory, A.; Dibadj, K.; Weiner, I.D. Rhabdomyolysis and Acute Renal Failure in a Patient Treated with Daptomycin. J. Antimicrob. Chemother. 2006, 57, 578-579. [CrossRef]

44. Cojutti, P.G.; Candoni, A.; Ramos-Martin, V.; Lazzarotto, D.; Zannier, M.E.; Fanin, R.; Hope, W.; Pea, F. Population Pharmacokinetics and Dosing Considerations for the Use of Daptomycin in Adult Patients with Haematological Malignancies. J. Antimicrob. Chemother. 2017, 72, 2342-2350. [CrossRef] 
45. Carugati, M.; Bayer, A.S.; Miró, J.M.; Park, L.P.; Guimarães, A.C.; Skoutelis, A.; Fortes, C.Q.; Durante-Mangoni, E.; Hannan, M.M.; Nacinovich, F.; et al. High-Dose Daptomycin Therapy for Left-Sided Infective Endocarditis: A Prospective Study from the International Collaboration on Endocarditis. Antimicrob. Agents Chemother. 2013, 57, 6213-6222. [CrossRef] [PubMed]

46. Seaton, R.A.; Menichetti, F.; Dalekos, G.; Beiras-Fernandez, A.; Nacinovich, F.; Pathan, R.; Hamed, K. Evaluation of Effectiveness and Safety of High-Dose Daptomycin: Results from Patients Included in the European Cubicin $\left({ }^{\circledR}\right)$ Outcomes Registry and Experience. Adv. Ther. 2015, 32, 1192-1205. [CrossRef] [PubMed]

47. Reiber, C.; Senn, O.; Müller, D.; Kullak-Ublick, G.A.; Corti, N. Therapeutic Drug Monitoring of Daptomycin: A Retrospective Monocentric Analysis. Ther. Drug Monit. 2015, 37, 634-640. [CrossRef] [PubMed]

48. Di Paolo, A.; Tascini, C.; Polillo, M.; Gemignani, G.; Nielsen, E.I.; Bocci, G.; Karlsson, M.O.; Menichetti, F.; Danesi, R. Population Pharmacokinetics of Daptomycin in Patients Affected by Severe Gram-Positive Infections. Int. J. Antimicrob. Agents 2013, 42, 250-255. [CrossRef]

49. Goutelle, S.; Roux, S.; Gagnieu, M.-C.; Valour, F.; Lustig, S.; Ader, F.; Laurent, F.; Chidiac, C.; Ferry, T. Pharmacokinetic Variability of Daptomycin during Prolonged Therapy for Bone and Joint Infections. Antimicrob. Agents Chemother. 2016, 60, 3148-3151. [CrossRef]

50. Barreau, S.; Benaboud, S.; Kernéis, S.; Moachon, L.; Blanche, P.; Groh, M.; Massias, L.; Treluyer, J.-M.; Poyart, C.; Raymond, J. Staphylococcus Aureus Osteo-Articular Infection: Usefulness of the Determination of Daptomycin Serum Concentration to Explain a Treatment Failure. Int. J. Clin. Pharmacol. Ther. 2016, 54, 923-927. [CrossRef]

51. Bozdogan, B.; Appelbaum, P.C. Oxazolidinones: Activity, Mode of Action, and Mechanism of Resistance. Int. J. Antimicrob. Agents 2004, 23, 113-119. [CrossRef]

52. Mendes, R.E.; Deshpande, L.M.; Jones, R.N. Linezolid Update: Stable in Vitro Activity Following More than a Decade of Clinical Use and Summary of Associated Resistance Mechanisms. Drug Resist. Updates 2014, 17, 1-12. [CrossRef]

53. Bassetti, M.; Baguneid, M.; Bouza, E.; Dryden, M.; Nathwani, D.; Wilcox, M. European Perspective and Update on the Management of Complicated Skin and Soft Tissue Infections Due to Methicillin-Resistant Staphylococcus Aureus after More than 10 Years of Experience with Linezolid. Clin. Microbiol. Infect. 2014, 20 (Suppl. 4), 3-18. [CrossRef]

54. Gerson, S.L.; Kaplan, S.L.; Bruss, J.B.; Le, V.; Arellano, F.M.; Hafkin, B.; Kuter, D.J. Hematologic Effects of Linezolid: Summary of Clinical Experience. Antimicrob. Agents Chemother. 2002, 46, 2723-2726. [CrossRef]

55. Brier, M.E.; Stalker, D.J.; Aronoff, G.R.; Batts, D.H.; Ryan, K.K.; O’Grady, M.; Hopkins, N.K.; Jungbluth, G.L. Pharmacokinetics of Linezolid in Subjects with Renal Dysfunction. Antimicrob. Agents Chemother. 2003, 47, 2775-2780. [CrossRef]

56. Cattaneo, D.; Gervasoni, C.; Cozzi, V.; Castoldi, S.; Baldelli, S.; Clementi, E. Therapeutic Drug Management of Linezolid: A Missed Opportunity for Clinicians? Int. J. Antimicrob. Agents 2016, 48, 728-731. [CrossRef] [PubMed]

57. Rayner, C.R.; Forrest, A.; Meagher, A.K.; Birmingham, M.C.; Schentag, J.J. Clinical Pharmacodynamics of Linezolid in Seriously Ill Patients Treated in a Compassionate Use Programme. Clin. Pharmacokinet. 2003, 42, 1411-1423. [CrossRef]

58. Abdul-Aziz, M.H.; Alffenaar, J.-W.C.; Bassetti, M.; Bracht, H.; Dimopoulos, G.; Marriott, D.; Neely, M.N.; Paiva, J.-A.; Pea, F.; Sjovall, F.; et al. Antimicrobial Therapeutic Drug Monitoring in Critically Ill Adult Patients: A Position Paper. Intensive Care Med. 2020, 46, 1127-1153. [CrossRef] [PubMed]

59. Pea, F.; Viale, P.; Cojutti, P.; Del Pin, B.; Zamparini, E.; Furlanut, M. Therapeutic Drug Monitoring May Improve Safety Outcomes of Long-Term Treatment with Linezolid in Adult Patients. J. Antimicrob. Chemother. 2012, 67, 2034-2042. [CrossRef]

60. Matsumoto, K.; Takeshita, A.; Ikawa, K.; Shigemi, A.; Yaji, K.; Shimodozono, Y.; Morikawa, N.; Takeda, Y.; Yamada, K. Higher Linezolid Exposure and Higher Frequency of Thrombocytopenia in Patients with Renal Dysfunction. Int. J. Antimicrob. Agents 2010, 36, 179-181. [CrossRef] [PubMed]

61. Nukui, Y.; Hatakeyama, S.; Okamoto, K.; Yamamoto, T.; Hisaka, A.; Suzuki, H.; Yata, N.; Yotsuyanagi, H.; Moriya, K. High Plasma Linezolid Concentration and Impaired Renal Function Affect Development of Linezolid-Induced Thrombocytopenia. J. Antimicrob. Chemother. 2013, 68, 2128-2133. [CrossRef]

62. Tsuji, Y.; Holford, N.H.G.; Kasai, H.; Ogami, C.; Heo, Y.-A.; Higashi, Y.; Mizoguchi, A.; To, H.; Yamamoto, Y. Population Pharmacokinetics and Pharmacodynamics of Linezolid-Induced Thrombocytopenia in Hospitalized Patients. Br. J. Clin. Pharmacol. 2017, 83, 1758-1772. [CrossRef]

63. Im, W.B.; Choi, S.H.; Park, J.-Y.; Choi, S.H.; Finn, J.; Yoon, S.-H. Discovery of Torezolid as a Novel 5-Hydroxymethyl-Oxazolidinone Antibacterial Agent. Eur. J. Med. Chem. 2011, 46, 1027-1039. [CrossRef]

64. Shaw, K.J.; Poppe, S.; Schaadt, R.; Brown-Driver, V.; Finn, J.; Pillar, C.M.; Shinabarger, D.; Zurenko, G. In Vitro Activity of TR-700, the Antibacterial Moiety of the Prodrug TR-701, against Linezolid-Resistant Strains. Antimicrob. Agents Chemother. 2008, 52, 4442-4447. [CrossRef]

65. Prokocimer, P.; Bien, P.; Surber, J.; Mehra, P.; DeAnda, C.; Bulitta, J.B.; Corey, G.R. Phase 2, Randomized, Double-Blind, DoseRanging Study Evaluating the Safety, Tolerability, Population Pharmacokinetics, and Efficacy of Oral Torezolid Phosphate in Patients with Complicated Skin and Skin Structure Infections. Antimicrob. Agents Chemother. 2011, 55, 583-592. [CrossRef] [PubMed]

66. Schaadt, R.; Sweeney, D.; Shinabarger, D.; Zurenko, G. In Vitro Activity of TR-700, the Active Ingredient of the Antibacterial Prodrug TR-701, a Novel Oxazolidinone Antibacterial Agent. Antimicrob. Agents Chemother. 2009, 53, 3236-3239. [CrossRef] [PubMed] 
67. Shaw, K.J.; Barbachyn, M.R. The Oxazolidinones: Past, Present, and Future: The Oxazolidinones: Past, Present, and Future. Ann. N. Y. Acad. Sci. 2011, 1241, 48-70. [CrossRef] [PubMed]

68. Grau, S.; Ferrández, O.; Urbina, O.; Espona, M.; Salas, E.; Ferrández, I. Potential Role of Tedizolid Phosphate in the Treatment of Acute Bacterial Skin Infections. Drug Des. Dev. Ther. 2013, 7, 243. [CrossRef]

69. Flanagan, S.; Fang, E.; Muñoz, K.A.; Minassian, S.L.; Prokocimer, P.G. Single- and Multiple-Dose Pharmacokinetics and Absolute Bioavailability of Tedizolid. Pharmacotherapy 2014, 34, 891-900. [CrossRef]

70. Housman, S.T.; Pope, J.S.; Russomanno, J.; Salerno, E.; Shore, E.; Kuti, J.L.; Nicolau, D.P. Pulmonary Disposition of Tedizolid Following Administration of Once-Daily Oral 200-Milligram Tedizolid Phosphate in Healthy Adult Volunteers. Antimicrob. Agents Chemother. 2012, 56, 2627-2634. [CrossRef]

71. Sahre, M.; Sabarinath, S.; Grant, M.; Seubert, C.; DeAnda, C.; Prokocimer, P.; Derendorf, H. Skin and Soft Tissue Concentrations of Tedizolid (Formerly Torezolid), a Novel Oxazolidinone, Following a Single Oral Dose in Healthy Volunteers. Int. J. Antimicrob. Agents 2012, 40, 51-54. [CrossRef]

72. Flanagan, S.D.; Bien, P.A.; Muñoz, K.A.; Minassian, S.L.; Prokocimer, P.G. Pharmacokinetics of Tedizolid Following Oral Administration: Single and Multiple Dose, Effect of Food, and Comparison of Two Solid Forms of the Prodrug. Pharmacotherapy 2014, 34, 240-250. [CrossRef]

73. Roger, C.; Roberts, J.A.; Muller, L. Clinical Pharmacokinetics and Pharmacodynamics of Oxazolidinones. Clin. Pharm. 2018, 57, 559-575. [CrossRef]

74. Flanagan, S.; Passarell, J.; Lu, Q.; Fiedler-Kelly, J.; Ludwig, E.; Prokocimer, P. Tedizolid Population Pharmacokinetics, Exposure Response, and Target Attainment. Antimicrob. Agents Chemother. 2014, 58, 6462-6470. [CrossRef]

75. Flanagan, S.; Prokocimer, P. Reduction in Tedizolid Plasma Exposure among End-Stage Renal Disease Patients Undergoing Dialysis Is Explained by Variations in Ideal Body Weight. Antimicrob. Agents Chemother. 2016, 60, 3246-3247. [CrossRef]

76. Lodise, T.P.; Bidell, M.R.; Flanagan, S.D.; Zasowski, E.J.; Minassian, S.L.; Prokocimer, P. Characterization of the Haematological Profile of 21 Days of Tedizolid in Healthy Subjects. J. Antimicrob. Chemother. 2016, 71, 2553-2558. [CrossRef] [PubMed]

77. Ong, V.; Flanagan, S.; Fang, E.; Dreskin, H.J.; Locke, J.B.; Bartizal, K.; Prokocimer, P. Absorption, Distribution, Metabolism, and Excretion of the Novel Antibacterial Prodrug Tedizolid Phosphate. Drug Metab. Dispos. 2014, 42, 1275-1284. [CrossRef] [PubMed]

78. Bradley, J.S.; Flanagan, S.D.; Arrieta, A.C.; Jacobs, R.; Capparelli, E.; Prokocimer, P. Pharmacokinetics, Safety and Tolerability of Single Oral or Intravenous Administration of $200 \mathrm{Mg}$ Tedizolid Phosphate in Adolescents. Pediatric Infect. Dis. J. 2016, 35, 628-633. [CrossRef] [PubMed]

79. Yu, H.; Pan, C.; Xie, Q.; Zheng, Y.; Hu, Y.; Lin, Y. Simultaneous Determination of Tedizolid and Linezolid in Rat Plasma by Ultra Performance Liquid Chromatography Tandem Mass Spectrometry and Its Application to a Pharmacokinetic Study. J. Chromatogr. B 2016, 1011, 94-98. [CrossRef]

80. Deshpande, D.; Srivastava, S.; Pasipanodya, J.G.; Lee, P.S.; Gumbo, T. Tedizolid Is Highly Bactericidal in the Treatment of Pulmonary Mycobacterium Avium Complex Disease. J. Antimicrob. Chemother. 2017, 72, i30-i35. [CrossRef]

81. Park, A.; Young, J.; Wang, J.; Jayne, J.; Fukushima, L.; Rao, A.P.; D’Argenio, D.Z.; Beringer, P.M. Pharmacokinetics of Tedizolid in Plasma and Sputum of Adults with Cystic Fibrosis. Antimicrob. Agents Chemother. 2018, 62. [CrossRef]

82. Stainton, S.M.; Monogue, M.L.; Baummer-Carr, A.; Shepard, A.K.; Nugent, J.F.; Kuti, J.L.; Nicolau, D.P. Comparative Assessment of Tedizolid Pharmacokinetics and Tissue Penetration between Diabetic Patients with Wound Infections and Healthy Volunteers via In Vivo Microdialysis. Antimicrob. Agents Chemother. 2018, 62, e01880-17. [CrossRef]

83. Dorn, C.; Schießer, S.; Wulkersdorfer, B.; Hitzenbichler, F.; Kees, M.G.; Zeitlinger, M. Determination of Free Clindamycin, Flucloxacillin or Tedizolid in Plasma: Pay Attention to Physiological Conditions When Using Ultrafiltration. Biomed. Chromatogr. 2020, 34, e4820. [CrossRef]

84. Tsuji, Y.; Numajiri, M.; Ogami, C.; Kurosaki, F.; Miyamoto, A.; Aoyama, T.; Kawasuji, H.; Nagaoka, K.; Matsumoto, Y.; To, H.; et al. Development of a Simple Method for Measuring Tedizolid Concentration in Human Serum Using HPLC with a Fluorescent Detector. Medicine 2021, 100, e28127. [CrossRef]

85. Sandaradura, I.; Alffenaar, J.-W.; Cotta, M.O.; Daveson, K.; Day, R.O.; Van Hal, S.; Lau, C.; Marriott, D.J.E.; Penm, J.; Roberts, J.A.; et al. Emerging Therapeutic Drug Monitoring of Anti-Infective Agents in Australian Hospitals: Availability, Performance and Barriers to Implementation. Br. J. Clin. Pharm. 2022, 88, 669-679. [CrossRef] [PubMed]

86. Koch, B.C.P.; Muller, A.E.; Hunfeld, N.G.M.; de Winter, B.C.M.; Ewoldt, T.M.J.; Abdulla, A.; Endeman, H. Therapeutic Drug Monitoring of Antibiotics in Critically Ill Patients: Current Practice and Future Perspectives With a Focus on Clinical Outcome. Ther. Drug Monit. 2022, 44, 11-18. [CrossRef] [PubMed] 